\title{
Responsibility to Respect: Why the Core Company Should Act When Affiliates Infringe Human Rights*
}

\author{
Radu Mares*
}

in

\begin{abstract}
R. Mares (ed.), The UN Guiding Principles on Business and Human Rights - Foundations and Implementation, Martinus Nijhoff Publishers (Leiden, Boston 2012) pp. 169-192
\end{abstract}

\section{Introduction}

This chapter discusses the treatment that Professor Ruggie's Guiding Principles offer for the responsibility to respect human rights (RtR) as applied to core companies whose affiliates' operations infringe human rights. The issue is about a core company's responsibility to act to address abuses that occur towards the periphery of its group or network. The fairness of globalisation is often questioned with examples from industries where business enterprises are structured along buyer-supplier, parent-subsidiary and joint venture arrangements. Exportoriented labour-intensive industries and extractive industries are cases in point. The concern here is that the RtR raises difficult issues when applied to a business group or network as opposed to a single business entity.

Ruggie clearly entertains a responsibility for core companies. What remains rather unclear, however, is why the core company should have a responsibility to act when it did not contribute through its own decisions in any way to those abuses, but was merely associated, by virtue of its business relationships, with its affiliates. This scenario is clearly distinguishable from that of core companies taking decisions that have rippling effects on affiliates and thus have a role in the abuses $;{ }^{1}$ this scenario is less problematic and is not covered in this chapter. These two situations - contribution or mere association - where a core company's RtR may be brought up in the discussion are very different and require, it is submitted, a more critical treatment than they received in the Ruggie reports.

\footnotetext{
* This is the final version of the chapter. For references to exact pages, please refer either to this on-line document or to the formatted version in the book.

${ }^{*}$ Senior researcher, Raoul Wallenberg Institute of Human Rights and Humanitarian law, Lund, Sweden.

${ }^{1}$ Ruggie referred to 'brand-induced problems', such as flexible production, fast turnaround, surge orders, changed orders and so on. J. G. Ruggie, Remarks Delivered at Forum on Corporate Social Responsibility, Bamberg, Germany, 14 June 2006.
} 
The situations that give concern here are easy to exemplify: a buyer company purchases goods from a supplier, which independent of any decisions of the buyer, uses child and forced labour; a parent company has a subsidiary overseas, which independent of any decisions of the parent, destroys the livelihood of local populations through pollution and repressive practices, alone or in complicity with local entities. In these situations none of the core company's decisions contributes to the abuses perpetrated by affiliates against right holders overseas. Are these buyer and parent companies absolved of any responsibility in face of their affiliate's misconduct? If not, on what conceptual foundation would a core company's responsibility to act be based? So this chapter asks questions such as: Why does a core company have to act where it apparently did not contribute to its affiliates' harmful impacts? Why would an omission to act be blameworthy? These are foundational questions that precede any discussion of due diligence; in other words whether a responsibility exists precedes discussions about how that responsibility could and should be discharged. The appropriateness of Ruggie's due diligence recommendations is not challenged.

Ruggie's Guiding Principles are critically reviewed in section 2 for how they deal with the issue of a core company's responsibility to act. Section 3 seeks inspiration in tort jurisprudence ${ }^{2}$ in an attempt to justify a responsibility to act and thus reinforce Ruggie's foundational work on the RtR. Section 4 identifies some outstanding issues related to the RtR that could benefit from further research and attention in the post-Ruggie period.

\section{Ruggie's Treatment of RtR as Applied to Core Companies}

\subsection{Coverage of Core Companies}

Ruggie consistently addresses the RtR to "business enterprises, both transnational and others, regardless of their size, sector, location, ownership and structure". ${ }^{3}$ This is general enough to cover all types of business enterprises including core companies, but does Ruggie account explicitly for core companies? He clearly does and more specifically in all three Pillars of his Framework. Thus in Pillar 1, dealing with a state's duty to protect human rights, Ruggie lays

\footnotetext{
${ }^{2}$ Ferrari noted that " $[t]$ he definitions of tort, unerlaubte Handlung, délit, and fatto illecito, seem to differ greatly from one another in different legal systems. Nonetheless, there are certain requirements in all legal systems without which no right to claim damages exists. Without (1) an intentional or negligent act (or omission) which (2) causes (3) damages, no tortious liability results, i.e., no obligation to compensate for damages arises." F. Ferrari, 'Comparative Remarks on Liability for One's Own Acts', 15 Loyola of Los Angeles International and Comparative Law Journal (June 1993) p. 813 (references omitted).

${ }^{3}$ Guiding Principles on Business and Human Rights: Implementing the United Nations "Protect, Respect and Remedy" Framework, Report of the Special Representative of the Secretary-General on the issue of human rights and transnational corporations and other business enterprises, John Ruggie, A/HRC/17/31, 21 March 2011, (hereinafter Guiding Principles), p. 6.
} 
down as a foundational principle that "States should set out clearly the expectation that all business enterprises domiciled in their territory and/or jurisdiction respect human rights throughout their operations". 4 The Commentary exemplifies with "domestic measures with extraterritorial implications [such as] requirements on 'parent' companies to report on the global operations of the entire enterprise". Home countries are thus invited to address the core companies headquartered in their jurisdictions, and their international operations.

Furthermore, Pillar 2, dealing with the corporate responsibility to respect human rights, refers to "adverse human rights impacts either through their own activities or as a result of their business relationships with other parties". ${ }^{6}$ For further clarity, "'business relationships' are understood to include relationships with business partners, entities in its value chain, and any other non-State or State entity directly linked to its business operations, products or services". ${ }^{7}$ Abuses occurring in affiliate operations are thus clearly relevant in defining a core company's RtR.

Finally, in Pillar 3, which is dedicated to remedies, Ruggie is mindful of "legal, practical and other relevant barriers that could lead to a denial of access to remedy". Among the potential legal barriers lies "the way in which legal responsibility is attributed among members of a corporate group under domestic criminal and civil laws facilitates the avoidance of appropriate accountability". 9 In his previous reports, Ruggie expanded on issues of legal separation of entities and limited liability, most often in relation to judicial remedy discussions. ${ }^{10}$

So the special case of core companies is clearly acknowledged in Ruggie's reports. So are two different situations where their responsibility might be invoked; indeed, core companies at the top of business groups or at the centre of business networks can be related to abuses in different ways depending on whether a contribution to harm was made or not. According to Ruggie, the core companies are expected to:

\footnotetext{
${ }^{4}$ Ibid., para. I.A.2.

${ }^{5}$ Ibid., Commentary on para. I.A.2.

${ }^{6}$ Ibid., Commentary on para. II.A.13.

${ }^{7}$ Ibid., Commentary on para. II.A.13.

${ }^{8}$ Ibid., para. III.B.26.

${ }^{9}$ Ibid., Commentary on para. III.B.26.

${ }^{10}$ Ruggie wrote in 2008: "[T] he legal framework regulating transnational corporations operates much as it did long before the recent wave of globalization. A parent company and its subsidiaries continue to be construed as distinct legal entities. Therefore, the parent company is generally not liable for wrongs committed by a subsidiary, even where it is the sole shareholder, unless the subsidiary is under such close operational control by the parent that it can be seen as its mere agent. Furthermore, despite the transformative changes in the global economic landscape generated by offshore sourcing, purchasing goods and services even from sole suppliers remains an unrelated party transaction. Factors such as these make it exceedingly difficult to hold the extended enterprise accountable for human rights harm." Protect, Respect and Remedy: A Framework for Business and Human Rights, Report of the Special Representative of the Secretary-General on the issue of human rights and transnational corporations and other business enterprises, A/HRC/8/5, 2008, para. 13.
} 
(a) Avoid causing or contributing to adverse human rights impacts through their own activities, and address such impacts when they occur;

(b) Seek to prevent or mitigate adverse human rights impacts that are directly linked to their operations, products or services by their business relationships, even if they have not contributed to those impacts. ${ }^{11}$

So Ruggie draws an important distinction between contributing to affiliate's misconduct and merely being associated with a misbehaving affiliate. What are the consequences that flow from this distinction?

\subsection{Spectre of Overreaching}

So there can be responsibility for affiliate misconduct. That can be very demanding for business enterprises with presence in dozens of countries and counting their affiliates in the hundreds or thousands. As the core company has a responsibility to act when affiliates' operations infringe human rights, the spectre of overreaching begins to loom over the RtR. Ruggie deals with the problem in different ways. One is prioritising the most severe impacts. ${ }^{12}$ Thus, "business enterprises should first seek to prevent and mitigate those that are most severe or where delayed response would make them irremediable". ${ }^{13}$

Another way is to emphasise due diligence; the nature of the RtR is to act reasonably, with care. Ruggie further highlights the flexibility and context-specificity of due diligence measures. More or less advanced due diligence measures, requiring commensurate resources, might suffice depending on many factors: "The responsibility of business enterprises to respect human rights applies to all enterprises regardless of their size, sector, operational context, ownership and structure. Nevertheless, the scale and complexity of the means through which enterprises meet that responsibility may vary according to these factors and with the severity of the enterprise's adverse human rights impacts". ${ }^{14}$ Furthermore on business groups, he remarks that "the means through which a business enterprise meets its responsibility to respect human rights may also vary depending on whether, and the extent to which, it conducts business through a corporate group or individually". ${ }^{15}$

Finally, the buyer company is not expected to provide remediation regarding its suppliers' misbehaviour. The Commentary explains: "Where adverse impacts have occurred that the business enterprise has not caused or contributed to, but which are directly linked to its operations, products or services by a business relationship, the responsibility to respect human

\footnotetext{
${ }^{11}$ Guiding Principles, supra note 3, para. II.A.13. (emphasis added).

${ }^{12}$ See Ibid., Commentary on para. II.A.14, for a definition of 'severity'.

${ }^{13}$ Ibid., para. II.A.24.

${ }_{15}^{14}$ Ibid., para. II.A.14 (emphasis added).

15 Ibid., Commentary on para. II.A.14. This rather cryptic passage can be read in conjunction with the leverage discussion in the Commentary on para. II.B.19.
} 
rights does not require that the enterprise itself provide for remediation, though it may take a role in doing so." ${ }^{" 16}$ Only where the company has contributed to adverse impacts should it "provide for or cooperate in their remediation through legitimate processes". ${ }^{17}$ If Ruggie does not call for remediation, he still calls on buyers to prevent or mitigate potential impacts as part of their RtR. $^{18}$

So far Ruggie affirmed a core company's responsibility to act to address affiliate misdeeds. Also the separation of entities principle has been acknowledged as a business and legal reality. He also drew some limitations on the RtR, correct ones, but nonetheless limitations that inherently cannot answer the foundational question: why does a core company have to act where it apparently did not contribute to its affiliates' harmful impacts? Given that the separation principle can destroy the very foundation of a core company's responsibility to act, how does Ruggie square this principle with his RtR?

\subsection{Elephant in the Room: The Separation of Entities Norm}

Affiliates, from a legal perspective and a management of legal risks angle, are separate entities, and liability for misconduct remains localised with the affiliate. Only if the legal separation privilege is abused - the affiliate becoming an alter ego due to the core company controlling and dictating the affiliate's decisions ${ }^{19}$ - will the limited liability benefit be lifted and the core company become liable for an affiliate's misdeeds. ${ }^{20}$ The bottom-line is that sceptical core companies will ask: why are we held responsible for what third parties do when we did not contribute through our conduct to the harm inflicted?

Ruggie is too realistic to rely on the enterprise liability doctrine, which would overrule limited liability altogether. He does not advance this theory. Actually he deliberately does not advance any theory; one searches in vain for a principled treatment or guidance on how to allocate responsibility within corporate groups and networks. He deems it unnecessary for purposes of

\footnotetext{
${ }^{16}$ Ibid., Commentary on para. II.B.22.

${ }^{17}$ Ibid., para. II.B.22.

18 "Potential impacts should be addressed through prevention or mitigation, while actual impacts - those that have already occurred - should be a subject for remediation (Principle 22).” Ibid., Commentary on para. II.B.17.

${ }^{19}$ The ISO 26000 Guidance refers to control as "ability to dictate the decisions and activities of another party". It affirms responsibility "for the impacts of decisions and activities over which it has formal and/or de facto control (de facto control refers to situation where one organization has the ability to dictate the decisions and activities of another party, even where it does not have the legal or formal authority to do so)". ISO, Guidance on Social Responsibility, ISO 26000, 2010, para. 5.2.3.

${ }^{20}$ If not for its abuse by the core company, the legal separation of entities principle can be lifted for reasons of public policy. These public policies respond to national priorities that seem not to be necessarily present in the vast majority of international CSR cases. The 'enterprise liability' doctrine is exceptionally employed in some areas of law - tax, environmental, disclosure laws - but in tort law limited liability remains the rule: "In relation to tort liability enterprise analysis has made virtually no impact." P. Muchlinski, 'Limited liability and multinational enterprises: a case for reform?', 34 Cambridge Journal of Economics (2010) p. 920.
} 
RtR. What Ruggie does is to skilfully relegate legal separation as an issue of remedies, as a barrier to judicial remedies, discussed in Pillar $3 .^{21}$ Limited liability is thus downplayed as one among other barriers to remedies that should be lowered and dealt with in light of national legal specificities. In this way Ruggie effectively banishes legal separation from his concept of corporate responsibility elaborated in Pillar 2. He buries it in Pillar 3.

Does it matter that Ruggie places the separation of entities (legal) principle in Pillar 3 instead of Pillar 2? It would not really if the foundation for the core company's RtR was elaborated in a principled fashion and taking fully into account the separation principle. This treatment cannot be found in Ruggie's reports. Instead, Ruggie advances a RtR which is applicable to all companies, by drawing on soft law and societal expectations. ${ }^{22}$ When applied to the specific situation of core companies, this foundation proves at a closer analysis truly weak: it rests on a raw societal norm placed on a collision course with the separation of entities principle. ${ }^{23}$

\subsection{Verdict-Pluses and Deficiencies in Ruggie's Treatment}

Ruggie can be commended for the broad reach of his RtR. He has made it clear that a core company is responsible for its decisions that are the single cause or, most often, one of the causes of abuses occurring in affiliate operations. A company that contributed to harm breaches the RtR. The fact that such abuse took place in the operations of a legally separated entity such as suppliers is not decisive; in other words, the legal separation of entities does not derail the RtR. The core company will remain responsible for the impacts of its own decisions rippling through its enterprise. Such a company will appear complicit in abuse. Furthermore, Ruggie protects the RtR from the danger of overreaching through several limitations: severe impacts are prioritised, the due diligence steps are reasonable and take into account the context, and no remediation is expected from buyer companies.

Also praiseworthy is the clear affirmation that not only 'contribution' but also 'association' may trigger due diligence; it is important to cover both of these types of conduct of a core company. On the foundation of why core companies have to act when affiliates infringe rights without contribution from the core company, Ruggie fails to persuade. ${ }^{24}$ 'Contributing' to harm is rather

\footnotetext{
${ }^{21}$ Guiding Principles, supra note 3, Commentary on para. III.B.26.

${ }^{22}$ Business and human rights: Towards operationalizing the "protect, respect and remedy" framework, Report of the Special Representative of the Secretary-General on the issue of human rights and transnational corporations and other business enterprises, A/HRC/11/13, 22 April 2009, paras. 46-47.

${ }^{23}$ In another article I analysed Ruggie's reports looking for the building blocks that support the RtR: soft law as the authoritative policy pronouncements of states, a social norm reflecting societal expectations, and the complicity jurisprudence and discourse. See section III in R. Mares, 'A gap in the corporate responsibility to respect human rights', 36 Monash University Law Review (2011).

${ }^{24}$ Wood considered that "for all his emphasis on due diligence and complicity, Professor Ruggie is ultimately unclear about what kind and degree of connection to third-party human rights violations is sufficient to engage corporate responsibility". S. Wood, In Defence of the Sphere of Influence: Why the WGSR should Not Follow
} 
different from being 'associated' with the affiliate and this changes the RtR equation significantly. In the latter case the separation principle weighs much more heavily: its very purpose is to keep associated but separately incorporated entities under the law separate for purposes of liability.

The culpable conduct of the core company is not pinpointed conceptually and the limited liability norm is not treated as a structural feature of business groups raising challenges for the RtR, but as a feature of legal systems hindering access to judicial remedies. This is an ambiguous treatment of the separation principle that is problematic as it diverts attention from a key problem. The conflict herein between the RtR and the separation principle is real. A treatment combining silence and 'pillar playing' can only fail to persuade a critical reader anchored in legal and business realities. ${ }^{25}$ Ruggie's RtR concept for core companies is ingenious but ultimately unpersuasive.

My concern with Ruggie's treatment is that his RtR, despite being nominally applicable to multinational companies, will succumb to the pressure of the separation of entities principle and become atomised into a collection of RtR of each entity in the business group or network. Yes, the decisions of core companies rippling through affiliate operations will be covered by the RtR. ${ }^{26}$ But, to the extent that core companies leave affiliates to operate autonomously (under a general, strategic mandate of making profits without further direction or operational interference), the core companies are off the hook because the separation principle will defeat the non-conceptual affirmation of RtR that Ruggie makes. The core company's responsibility to act needs to be justified more carefully. ${ }^{27}$

Overall I would prefer to deem Ruggie's treatment as 'incomplete' rather than 'unpersuasive.' The RtR of core companies should not be discarded because Ruggie's is not flawed but has to be refined and strengthened. The coming sections aim to reinforce the foundation under Ruggie's

\footnotetext{
Professor Ruggie's Advice on Defining the Scope of Social Responsibility, 7 May 2010, <ssrn.com/abstract=1607438>.

${ }^{25}$ A report commissioned by the SRSG report noted that '[s]ome form of 'separate legal personality' and 'limited liability' exist in all of the 39 jurisdictions" surveyed and concluded that "[m]ost of the surveyed jurisdictions have similar approaches to the concepts of separate legal personality and limited liability - it is rare for the "corporate veil' to be pierced". Human rights and corporate law: trends and observations from a crossnational study conducted by the Special Representative, Addendum 2 to the Report, A/HRC/17/31/Add.2, 2011, paras. 31 and 49.

${ }^{26}$ This is consistent with current tort laws. For example, British courts dealt with the claims that mercury-poisoned South African workers raised against a UK-based parent company. The claimants alleged the parent's culpable conduct consisting of negligent design, transfer, set-up, operation, supervision and monitoring of intrinsically hazardous process. Sithole v. Thor Chemicals Holdings Ltd., [1999] EWCA (Civ) 706 (Eng.)

${ }^{27}$ Why this emphasis on justification? The Guiding Principles have already been endorsed unanimously by states in the Human Rights Council. Is this not enough legitimacy, authority and justification for the RtR? Arguably not if such 'soft law' or policy pronouncements of the HRC are in conflict with established cornerstones of business law, such as the separation of entities principle. Because such international soft law could not trump long lasting national hard law, soft law would be relegated to mere 'aspirations' and possibly discarded altogether in practice.
} 
RtR by pinpointing the culpable conduct of the core company and using jurisprudential insights to build an RtR argument in the 'shadow of law.' This conceptual treatment could render the foundation of RtR clearer and more legitimate, and make it able to handle better attacks from sceptics mindful of the separation of entities principle.

\section{Building Support for the RtR}

The aim of this section is to introduce key characterisations that can sustain a core company's responsibility to act. What is the culpable conduct of core companies? What is special about human rights in less developed countries? What is the nature of the resulting responsibility? Insights from negligence jurisprudence will be offered with reference to certain provisions from the American Law Institute's (ALI) Restatement of Torts ${ }^{28}$ and the Alien Tort Claims Act (ATCA) litigation in the US.

\subsection{Culpable Conduct of the Core Company}

In his treatment of the separation of entities principle, Ruggie rightly wishes to avoid offering an easy escape to companies: the mere thing an evasive company would have to do is to set up a legally separated subsidiary or write an outsourcing contract. If constrained by limited liability, the RtR would be defeated easily through legal formalities with the result of localising responsibility with some affiliates. As shown above, Ruggie's way out of this conundrum was to banish limited liability from Pillar 2 and account for it as a barrier to judicial remedies in Pillar 3. But, especially when 'association' rather than 'contribution' to harm is the imputed blameworthy conduct, it would be short-sighted to think about the separation of entities principle simply as a legal obstacle; it is more properly understood as a legal, economic and social norm. ${ }^{29}$

A more coherent treatment, though unavoidably more complex, which in the context of the Special Representative of the Secretary General mandate would not be an asset, would rightly begin by focusing on potential abuses of the legal separation principle. After that, Ruggie could have put the spotlight on the key moment when the core company attempts to shed responsibility for its association with the subsidiary. This key moment is not the decision to set up the subsidiary, but the decision of the core company to grant autonomy to the subsidiary. Notably, imputing the conduct of the autonomous subsidiary to its parent is way more difficult than in the situation of the subsidiary that remains under the strategic and especially the operational control of the parent. In the latter case, autonomy is by definition diminished or even extinguished altogether. In such a case, based on current 'lifting the corporate veil' or negligent control legal

\footnotetext{
${ }^{28}$ American Law Institute, Restatement (Second) of Torts (1965), (hereinafter Restatement of Torts)

${ }^{29}$ Mares, supra note 23.
} 
doctrines, victims could already without controversy go directly after the parent company. The parent's wrongful conduct is clear and consists in dictating decisions to the subsidiary and thus clearly causing or contributing to harm through its own actions.

Such intrusive conduct on the side of the parent company is not present when a subsidiary is autonomous. Still it is clear why such an autonomy-granting decision is problematic from a human rights angle: the core company sets up a separated entity in a dangerous environment (poorly governed developing country) and lets it loose with a certain mandate (profit-making) without any checks and oversight over subsidiary activities. Such an autonomy-granting decision creates risks for right holders overseas. It is for this decision that the core company should be held responsible under a due diligence standard. As a result, a duly diligent company would be free to set up subsidiaries but should retain some responsibility for initial structuring and ongoing oversight.

What about other affiliates, such as contractors? Ruggie covers them with the term 'relationships'. Again the obstacle is in the separation principle, only that this time the buyer company cannot be accused that it abuses the limited liability norm by setting up legally separated entities, such as subsidiaries; the buyer merely outsources to pre-existing entities, the contractors and suppliers. What could be the culpable decision here?

The key decision of the buyer is not that of outsourcing per se, but outsourcing to a risky contractor, a contractor that poses foreseeable risks of human rights abuse. While outsourcing in itself is legitimate, the decision to outsource to irresponsible contractors without vetting and oversight procedures is problematic. Notably, tort jurisprudence already has remarkable provisions in this area, to be discussed below, which Ruggie unfortunately does not exploit to establish a responsibility of buyer companies to act.

This boils down to saying that a core company's responsibility to act does not result naturally from a broad responsibility to respect, that is, 'to do no harm'; ${ }^{30}$ it is additional to that and needs to be justified separately. A public comment sent to Ruggie after the Draft Guiding Principles were unveiled in late 2010 makes this point rather clear when discussing the parent-subsidiary relationship. It happens that the Guiding Principles ended up being lapidary on the separation of entities principle, while the Draft version offered more insight into how Ruggie attempted to deal with business groups. ${ }^{31}$ In his comment on the Draft Principles, Muchlinsky, an authority in the field of corporate groups, wrote: "I am a little baffled why a subjective approach is taken to the

\footnotetext{
${ }^{30}$ Protect, Respect and Remedy, supra note 10, para. 24.

31 The Commentary on Principle 12 stated: "A corporate group may consider itself to be a single business enterprise, in which case the responsibility to respect human rights attaches to the group as a whole and encompasses both the corporate parent and its subsidiaries and affiliates. Alternatively, entities in a corporate group may consider themselves distinct business enterprises, in which case the responsibility to respect attaches to them individually and extends to their relationships with other entities - both within the group and beyond - that are connected to their activities." Draft Guiding Principles, Commentary on Principle 12, 2010.
} 
identification of the group. It opens the way for a purely subjective definition of which entities are in the group or not and allows individual directors to allocate human rights responsibility in the group as they see fit ... I think it is much easier to say that all entities in the group have a responsibility to respect human rights and that parent and holding companies have a responsibility to oversee that their subsidiaries respect human rights ..." ${ }^{\text {32 }}$

But the responsibility to oversee needs to be justified. As suggested herein, it helps whether this additional responsibility of core companies can be justified by identifying a culpable decision of the core company itself. Even more, it would be preferable to characterise the core company's conduct as a commission rather than omission and thus strengthen the foundation further.

\subsection{Conduct by Commission}

One of my aims has been to find a way to deal with the passivity of core companies in face of affiliate abuses. Pinpointing and reframing the core company's culpable conduct is a key move in the effort to attribute responsibility not for what third parties do, but for what the actor did when it entered into a business relationship that raised peculiar risks of harm. The parent company acted when it set up the subsidiary and then left it to its own devices in an environment riddled with risks of human rights abuses; the buyer company acted when it decided to outsource production without checking the human rights practices of its suppliers and to keep the relationship going when notices of abuse were provided.

It is important to reframe, if possible, inactions into actions. Culpability for omissions is always more problematic. As it was noted, "the prohibition of omissions is far more intrusive upon the individuals' autonomy and freedom than is the prohibition of acts, which is why the systematic imposition of (criminal or civil) liability for failures to act is to be resisted" ${ }^{33}$

This reframing is not unknown to tort jurisprudence. Thus Fletcher wrote that as the law of negligence evolved, "the failure to exercise due care - an omission - came to be seen as part of affirmative risks to others - the risks of driving, of medical care, of handling weapons, of manufacturing goods. In the context of these larger activities, the omission is but an epicycle on the arc of risk generated by the affirmative conduct. The omission becomes a minor part of the actor's assertive conduct ... The fault was not the passivity of an omission, but the affirmative wrong of creating an unreasonable risk. ${ }^{, 34}$ McCarthy wrote about the "conversion of omissions into actions, by simply taking a broader view of the activity". ${ }^{35}$

\footnotetext{
${ }^{32}$ P. Muchlinski, Comments on the Draft Guiding Principles for Business and Human Rights, January 2011, (emphasis added).

33 The Law Commission (UK), Participating in Crime, (LAW COM No 305), 2007, para. 3.26, <www.justice.gov.uk/lawcommission/docs/lc305_Participating_in_Crime_report.pdf>.

${ }^{34}$ G. P. Fletcher, 'The Fault of Not Knowing', 3 Theoretical Inquiries in Law (July 2002) p. 265 (emphasis added).

${ }^{35}$ F. B. McCarthy, 'Crimes of Omission in Pennsylvania', 68 Temple Law Review (Summer 1995) p. 633.
} 
A rather analogous situation is what Deakin discussed in the context of an employer's liability for the intentional torts of employees. ${ }^{36}$ Customarily, the employer is not liable for the intentional wrongdoings of its employees. But in Lister v. Hesley Hall (2001), Lord Clyde was concerned that "it becomes inappropriate to concentrate too closely on the particular act complained of" and therefore the intentional wrong can be seen as one aspect of a larger pattern of conduct. ${ }^{37}$ This being said, it should not be overlooked that when such reframing of omission into commission is performed, issues of proximity, remoteness and causality reassert themselves vigorously to limit potential liability. Therefore one needs to tread cautiously and see this as a reminder that we are still in the realm of exception from the no-liability-for-omissions rule. The foundation for a responsibility to act needs to be reinforced further.

The core company's responsibility to act needs to be further strengthened and limited to be legitimate. Not all misconduct of any affiliate should attract a responsibility to act from the core company. Only some risks of harm will be relevant. They have to do with the vulnerability of right holders in less developed countries. Noteworthy is that it will be a special type of vulnerability.

\subsection{Vulnerability of Stakeholders}

Vulnerability is a key concept in justifying a responsibility to act imposed on the core company. Some illustrations are in order. For local communities, setting up extractive operations on their land or in their neighbourhood can spell disaster. Dispossession of land, often without proper compensation; ${ }^{38}$ abuses by security forces against restless local populations; pollution that affects access to food, water, health and livelihoods; and unmitigated effects of migration inflows that typically trigger higher prices, put pressure on infrastructure, increase transmittable diseases and criminality are among the usual risks for local communities, especially where regulatory gaps loom wide. ${ }^{39}$ For indigenous people, with their special needs to have their way of life and culture preserved, the risks are obvious and well documented. ${ }^{40}$

Moving further to other sectors, such as in labour-intensive industries where production has been outsourced, the risks that employees encounter are well documented: child labour, discriminatory

\footnotetext{
${ }^{36}$ S. Deakin, 'Enterprise-Risk: The Juridical Nature of the Firm Revisited', 32 Industrial Law Journal (June 2003) p. 97.

37 Quoted in ibid. To keep liability for such torts within reasonable limits, courts devised the 'test of sufficient connection'. Ibid.

${ }^{38}$ R. Mares, 'Corporate responsibility and compliance with the law: land, dispossession and aftermath at Newmont's Ahafo project in Ghana', Business and Society Review (2011).

${ }^{39}$ Extractive Industries Review, Striking a Better Balance, World Bank, 2004; UNCTAD, World Investment Report 2007: Transnational Corporations, Extractive Industries and Development, 2007.

${ }^{40}$ Report of the Special Rapporteur on the situation of human rights and fundamental freedoms of indigenous people, Rodolfo Stavenhagen, E/CN.4/2003/90, p. 2.
} 
practices, union busting, and more broadly 'sweatshop' working conditions characterised by low pay, long hours, poor health and safety protections, and intimidation and abuse of all kinds. These practices are almost standard in factories where laws are weak, labour inspectors rare, and unions repressed.

The result is that right holders are in a state of vulnerability. To be clear, such vulnerability does not have to do with poverty, which is pervasive in less developed countries and exists even in developed countries where pockets of poverty persist. Neither does this refer to being vulnerable to harm from business operations; all residents in both developed and less developed countries are exposed to harm when industrial processes go wrong. It has to do with the absence of effective remedies. This is a specific type of vulnerability: that of being vulnerable to having no remedies when risks materialise. Such vulnerability comes precisely from regulatory gaps and the ineffective remedies right holders have at their disposal. These are the 'governance gaps' that Ruggie refers to in his writings. So the situation creating problems for the core company is not the risk of harm but the risk of unremedied harm in affiliate operations. Where right holders systematically lack institutional channels to contest human rights abuses and poor working conditions, this is disabling and highly problematic from a human rights perspective.

I propose that the issue of remedies is crucial for definitions of vulnerability. Were remedies at national level effective, a core company's action would be redundant. However where those remedies are ineffective, the responsibility of core companies becomes essential. So the interaction between responsibility to act (Pillar 2) and access to remedies (Pillar 3) is a substantive one, not a procedural one: ${ }^{41}$ the very existence of a core company's responsibility to act depends on the state of remedies practically available to right holders.

Now I turn to jurisprudence for further insights on when vulnerability and risks trigger a responsibility to act. The American Law Institute's Restatement of Torts will be used as illustration. Certain characterisations relevant to RtR as applied to core companies can be gleaned from tort jurisprudence in relation to elements such as foreseeability of harms, 'peculiar' risks, non-delegable duties, obligation of careful selection of contractors and obligation to take special precautions.

\subsection{Foreseeability of Risk of Harm in Affiliate Activities}

\footnotetext{
${ }^{41}$ The relationship between Pillars 2 and 3 was discussed by Catá Backer in 2009: "For the moment it is not clear whether the Third Pillar is merely the dependent on the substantive elaborations of the First and Second Pillars, or whether the Third Pillar serves as an independent source of substantive standards. It would seem that the later approach is more in keeping with the work of the SRSG. But the temptation to reduce the Third Pillar to a set of mechanics is still strong." L. Catá Backer, 'On the Evolution of the United Nations' "Protect-Respect-Remedy" Project: The State, the Corporation and Human Rights in a Global Governance Context', 9:1 Santa Clara J. int'l Law (2010).
} 
Previously I pinpointed the culpable conduct of the core company: the autonomy-granting decision after a subsidiary was set up, respectively the outsourcing to a contractor, with disregard to the risks of abuse posed in weakly governed host countries. Risks of abuse are foreseeable in both cases. The Restatement of Torts has a broad clause applicable to both settings discussed herein. Namely, section 302, which talks about an actor's negligent conduct where it involves an unreasonable risk of harm to another through the foreseeable action of a third person. ${ }^{42}$ This provision covers the negligent or intentional misconduct of the third party.

The Comment on section 302 explains the negligence in a situation "[w]here the actor has brought into contact or association with the other a person whom the actor knows or should know to be peculiarly likely to commit intentional misconduct, under circumstances which afford a peculiar opportunity or temptation for such misconduct". 43 This description seems tailormade for large infrastructure projects such as those in the extractive industry, especially in greenfield projects. There a parent company commences mining operations that are bound to bring in contact the local communities with new and potentially irresponsible actors, such as security forces, corrupt officials, abusive contractors, and the parent's own autonomous subsidiary. A positive find of minerals brings in all these actors that can and have committed human rights abuses against local communities.

One can argue that, by taking the decision to develop a mine (or more generally a large infrastructure project), the core company abroad brought local communities in contact with actors that were not present there before mining operations commenced. For this reason, the mining company has a responsibility to act and address risks presented by its subsidiary and its local partners. The undeniable fact is that setting up a mining operation does create risks of harm for local communities, risks that are more likely and severe when the legal frameworks are weak. A responsibility to act should be recognised to cover those parent companies based overseas that fail to influence their subsidiaries, which directly ${ }^{44}$ or indirectly through its partners infringed with impunity the rights of local communities.

The idea that harm is foreseeable is present in the case of contracting as well. ${ }^{45}$ If the core company does not select diligently a competent contractor, harm is likely to follow. Following

\footnotetext{
42 "A negligent act or omission may be one which involves an unreasonable risk of harm to another through either (a) the continuous operation of a force started or continued by the act or omission, or (b) the foreseeable action of the other, a third person, an animal, or a force of nature." Section 302, Restatement of Torts, supra note 28.

${ }^{43}$ Ibid., Section 302, Comment (emphasis added).

${ }^{44}$ Leigh Day \& Co, Shell accepts responsibility for oil spill in Nigeria, 3 August 2011, <www.leighday.co.uk/news/news-archive-2011/shell-accepts-responsibility-for-oil-spill-in>.

${ }^{45}$ Previously I presented the foreseeable risk of harm when the company brought right holders into contact with perpetrators. This seems to work much better for contractors that harm non-employees, such as local communities harmed by security contractors. They were brought into contact by the company. But one cannot argue that the buyer brought the supplier and its employees into contact, as they were already employed before the order was
} 
the Restatement's section 411, the tort idea of 'proper selection' holds the hiring party liable for harm to third persons for "failure to exercise reasonable care to employ a competent and careful contractor". 46 The Restatement explains that the "words 'competent and careful contractor' denote a contractor who possesses the knowledge, skill, experience, and available equipment which a reasonable man would realize that a contractor must have in order to do the work which he is employed to do without creating unreasonable risk of injury to others, and who also possesses the personal characteristics which are equally necessary". 47

So an employer can be held liable for the actions of an independent contractor if the employer was negligent in hiring or retaining that contractor, if the employer knew, or should have known with reasonable care, that the contractor was reckless or incompetent. Calvert Hanson mentions a US case that concerned

an inexperienced independent contractor hired to dispose of pressurized cylinders containing hazardous chemicals. The Virginia Supreme Court concluded that there was "no conflict in the evidence of [the hiring party's] failure to investigate" and that "there can be no doubt that [the independent contractor's] incompetence was the ultimate cause of the losses claimed in this case." In this case, the failure to thoroughly investigate the contractor coupled with the hiring of the untrained contractor was the cause of the harm, thus providing the requisite linkage. ${ }^{48}$

Another case involved a company that had an "aggressive indifference to the fitness of its vendor", indifference that could have resulted in liability under a negligent selection theory. ${ }^{49}$

This clause on negligent selection covers foreseeable risks in general. Should 'peculiar' risks arise, not only does an obligation of 'proper selection' apply but also an additional obligation to 'take special precautions'. Section 413 of the Restatement indicates that special precautions are called for when an independent contractor poses a peculiar risk of harm; the employer might be liable if these precautions are not taken. ${ }^{50}$ The Commentary further explains that

placed. So employees are not properly covered by this reasoning of bringing in contact under Section 302. Instead they are covered by the specific provisions on contracting such as sections 411 and 413 below.

46 "An employer is subject to liability for physical harm to third persons caused by his failure to exercise reasonable care to employ a competent and careful contractor (a) to do work which will involve a risk of physical harm unless it is skillfully and carefully done, or (b) to perform any duty which the employer owes to third persons." Section 411, Restatement of Torts, supra note 28.

${ }^{47}$ Ibid., Section 411, Comment a.

${ }^{48}$ L. S. Calvert Hanson, 'Employers Beware! Negligence in the Selection of an Independent Contractor Can Subject You to Legal Liability', 5 University of Miami Business Law Journal (Spring 1995) p. 129 (references omitted).

${ }^{49}$ Ibid.

${ }^{50}$ The fulltext reads: "One who employs an independent contractor to do work which the employer should recognize as likely to create, during its progress, a peculiar unreasonable risk of physical harm to others unless special precautions are taken, is subject to liability for physical harm caused to them by the absence of such precautions if the employer (a) fails to provide in the contract that the contractor shall take such precautions, or (b) fails to exercise reasonable care to provide in some other manner for the taking of such precautions." Section 413, Restatement of Torts, supra note 28. 
[t]his Section is concerned with special risks, peculiar to the work to be done, and arising out of its character, or out of the place where it is to be done, against which a reasonable man would recognize the necessity of taking special precautions ... "Peculiar" does not mean that the risk must be one which is abnormal to the type of work done, or that it must be an abnormally great risk ... The court stated that peculiar risk did not imply an abnormal risk, but rather, a recognizable danger arising from the work itself which has gone untended. Whether the work involved created a peculiar risk was a question of fact. ${ }^{51}$

In tort it seems that 'peculiar' risks arise out of 'inherently dangerous' activities. ${ }^{52}$ In many corporate social responsibility (CSR) cases it would be too much of a stretch to consider risks of unremedied harm as 'peculiar'. But given the strong normativity of human rights and the absence of remedies, which in classical tort are available through tort litigation, I would argue that risks of unremedied harm are a special category of 'peculiar-light' risks that require some special precautions to be taken, some responsibility to act. This characterisation of risks of unremedied harm as 'peculiar' risks is not decisive as we can always default on 'foreseeable risks'; but the characterisation can further strengthen the legitimacy of a responsibility to act and covers not only initial selection but some on-going oversight of the supplier as well.

Noteworthy, ATCA cases often refer to the tort of negligence. In Doe v. Unocal (Burma), the broad argument was that "Unocal owed a duty to plaintiffs to exercise due care in conducting its international ventures". 53 Plaintiffs argued various doctrines, including negligence, negligent hiring, negligent supervision, ${ }^{54}$ and negligent infliction of emotional distress. In Doe v. Exxon (Indonesia), the plaintiffs alleged that the "[d]efendants failed to exercise reasonable care in selecting, hiring, retaining and contracting" with the military and police forces; the defendants knew or reasonably should have known that the military and police forces would violate rights. ${ }^{55}$ The judge dealt at length with issues of negligence in selection. ${ }^{56}$ In Roe v. Bridgestone (Liberia), the plaintiffs argued, under Californian law, that the defendants were negligent and reckless because they knew that the plaintiffs were subjected to forced labour and, because they

\footnotetext{
${ }^{51}$ Ibid., Section 416, Comment b (refers to and makes applicable Section 413).

${ }^{52}$ Activities deemed to be inherently dangerous are the construction of reservoirs, handling of vicious animals, work involving electric wires, blasting, the production of firework exhibitions, and crop dusting. U. Gasser, Responsibility for human rights violations, acts or omissions, within the 'sphere of influence' of companies, The Berkman Center for Internet \& Society at Harvard Law School, Research Publication No. 2007-12, 2007.

${ }^{53}$ Doe v. Unocal, <upload.wikimedia.org/wikipedia/commons/b/b0/Doe_v_Unocal_Plaintiffs_Complaint_and_conformed_face_sheet. pdf $>$.

${ }^{54}$ While negligent selection covers independent contractors, negligent supervision covers agents that the company controls and instructs. Independent contractors and agents are very different categories; the former conducts its enterprise independently as it fulfils the contract with the buyer, while the latter conducts its activities under the control and instructions of the principal. Therefore the principal has a duty of supervision, which the employer of the contractor does not.

${ }^{55}$ Doe v. Exxon (original complaint), 11 June 2001, para. 112, <www.iradvocates.org/exxoncomplaint.pdf>.

${ }^{56}$ L. F. Oberdorfer (United States District Judge), Memorandum \& Opinion, John Doe I, et al., v. Exxon Mobil Corporation, et al., Civil Action No. 01-1357 (LFO), United States District Court for the District of Columbia, 27 August 2008, <ecf.dcd.uscourts.gov/cgi-bin/show_public_doc?2001cv1357-365>.
} 
failed to exercise reasonable care to prevent these harms, they increased the risk of injury to the plaintiffs. The plaintiffs also claimed that the defendants were negligent in hiring and supervision, which was a major cause of the conditions allowing forced labour on the plantation. $^{57}$ In Doe v. Chiquita Brands International (Columbia), the plaintiffs invoked the company's negligent infliction of emotional distress as well as negligence, negligent hiring, and negligence per se. ${ }^{58}$

Surprisingly though, and despite numerous ATCA complaints invoking negligence law, CSR writings seeking to justify corporate responsibilities have appealed predominantly to complicity jurisprudence rather than negligence. The CSR discourse is overwhelmingly coated in complicity and 'aiding and abetting' terminology rather than negligence. This is justifiable when the core company 'contributed' to harm, but hardly so when the core company was merely being passive and 'associated' through normal business relationship with its affiliate. ${ }^{59}$

It should be remembered that this discussion of the buyer-contractor relation covers situations where the buyer did not impose stringent contractual requirements that forced the supplier into corner-cutting and labour rights abuses; ${ }^{60}$ then the buyer's responsibility would have followed directly. Here the contract is assumed as in line with industry practices and thus apparently fair. Does this mean the buyer has no further responsibility to act? Does a fair contract mean that the buyer has a fair relationship with the suppliers' employees and other right holders? Writing a fair outsourcing contract is necessary but not sufficient to make the buyer's conduct legitimate; the buyer company can appear negligent unless it engages in careful selection and takes further precautions against risks elevated to 'peculiar risk' status. Buyers cannot claim no responsibility to act in regard to the abusive practices of suppliers. It is blameworthy to disregard foreseeable and peculiar risks to workers arising out of the process through which the buyer's goods are made.

\footnotetext{
${ }^{57}$ Plaintiffs' memorandum of points and authorities in opposition to Defendants' motion to dismiss, 20 March 2006, <www.iradvocates.org/Opposition\%20to\%20Motion\%20to\%20Dismiss040306.pdf>.

${ }^{58}$ Doe v. Chiquita Brands International, 18 July 2007, pp. 27-29, <www.earthrights.org/sites/default/files/legal/cbifinal-complaint-signed.pdf $>$.

${ }_{59}$ Among the exceptions is a study that took note of responsibility of the employer for the acts of the independent contractor: "In certain cases, the concept of negligence may impute to business entities a minimum duty to avoid harming others in an unreasonable fashion ... For example, if a company hires members of another state's military forces for security purposes but fails to take sufficient measures to prevent them from torturing civilians in the course of providing "security," it is conceivable that the company's failure to implement protective measures could result in a determination of negligence, and that it would be required by a court to compensate the harmed individuals." International Peace Academy and FAFO AIS, Business and International Crimes: Assessing the Liability of Business Entities for Grave Violations of International Law, Executive Summary, 2004, p. 21.

${ }^{60}$ In the Wal-Mart case the plaintiffs alleged that the company "knowingly impose[d] time and price requirements in its supplier agreement that necessarily result[ed] in abysmal conditions in Plaintiffs' factories". S. Meyerzon Nagiel, 'An Overlooked Gateway to Victim Compensation: How States Can Provide a Forum for Human Rights Claims', Columbia Journal of Transnational Law (2007). In the Bridgestone (Liberia) case, plaintiffs alleged that the buyer breaches its RtR by unfair setting contractual terms, <www.iradvocates.org/Firestone\%20Complaint\%20Final1105.pdf>.
} 


\subsection{Evolution of Law}

The analysis so far deliberately rejected a view that such risks of unremedied harm in affiliate operations is normal, routine risks of business activity that fall exclusively within the responsibility of the affiliate. While the rule of non-liability applies and will not be abandoned, jurisprudence has amassed quite a number of exceptions to this rule. Here we want to note this remarkable evolution of tort jurisprudence and put RtR discussions into perspective. The limited liability principle does not operate in a social vacuum and does not offer a blanket protection to core companies.

The legal rule was explained in the Restatement of Torts: "[S]ince the employer has no power of control over the manner in which the work is to be done by the contractor, it is to be regarded as the contractor's own enterprise, and he, rather than the employer, is the proper party to be charged with the responsibility of preventing the risk, and bearing and distributing it ..." "61 As Pearce noted, "the rationale behind this rule is that an independent contractor, by definition, does not fall under the control of an employer. While the employer and independent contractor agree on the task to be completed, the independent contractor has control of its own work and the manner in which it performs the work". ${ }^{2}$

Interestingly though, as the Restatement points out, the law has progressed via the recognition of a large number of exceptions to the general rule. These exceptions are so numerous now and have so far 'eroded the 'general rule,' that it can now be said to be 'general' only in the sense that it is applied where no good reason is found for departing from it". ${ }^{63}$ The reasons, that is, policy reasons in developed countries, why tort law looks beyond independent contractors are quite clear. One has to do with the fact that such contractors are simply individuals that may not be solvent, and thus not in a position to satisfy tort judgments against them because they are not in business anymore. Also the employer might have a possibility of effective loss distribution in ways that might not always be feasible for the independent contractor. ${ }^{64}$ Another reason is that tort aims to "provide a timely and effective remedy for victims who do not have to worry about the identity of the contractor". ${ }^{65}$ Finally, other policy factors play a role in anchoring such duties, as McLachlin explained: "the reasonable expectation of vulnerable parties in protective

\footnotetext{
${ }^{61}$ Section 409, Comment b, Restatement of Torts, supra note 28.

62 J. A. Pearce II, 'The Dangerous Intersection of Independent Contractor Law and the Immigration Reform and Control Act: The Impact of the Wal-Mart Settlement', 10 Lewis \& Clark Law Review (Fall 2006) p. 597 (references omitted) (emphasis added).

${ }^{63}$ Section 409, Comment b, Restatement of Torts, supra note 28.

${ }^{64}$ E. Adjin-Tettey, 'Accountability of Public Authorities through Contextualized Determinations of Vicarious Liability and Non-Delegable Duties', 57 University of New Brunswick Law Journal (2007) p. 46.

65 Ibid.
} 
relationships" and "the practical difficulties that such persons might experience in trying to obtain compensation from independent contractors". 66

The above reference to vulnerability resonates well with the present CSR argument, although vulnerability in protective relationships covers narrower situations such as that of children in foster homes. In CSR situations, the vulnerability resulting from risks of unremedied harms is different, but still they both have in common the need to account for special circumstances that those who suffer the harm find themselves in. Proponents of the RtR can take note of the evolution of tort law in this area where those harmed by outsourced operations were deemed vulnerable enough to obtain recourse against the contractor's employer. Law has proved highly dynamic, singled out blameworthy conduct and legitimised claims against entities' outsourcing activities despite the separation of entities principle. Also in relation to vulnerability, jurisprudence offers us another useful categorisation: that of non-delegable duties.

\subsection{Responsibility to Act as Non-Delegable Duty to Maintain Safety}

The notion of non-delegability has been articulated in tort jurisprudence to cover situations of vulnerability. Adjin-Tettey deems it a "unique pragmatic approach in response to the special vulnerability of potential victims ... There does not appear to be a closed category of protective relationships for which non-delegable duties arise. This seems to be a flexible approach deployed for justice in particular cases where to do otherwise would effectively leave plaintiffs without a remedy". 67

This explicit emphasis on vulnerability and lack of remedy invites us to characterise the core company's responsibility to act as a responsibility to maintain safety and a non-delegable duty. At its core, the non-delegability doctrine implies that outsourcing operations does not result automatically in outsourcing responsibility for the safety of activities. The Restatement explains that '[ $\mathrm{t}]$ he words 'non-delegable duty' do not imply that there are duties which cannot be discharged by appointing others to perform them. They describe duties the performance of which can properly be delegated to another person, but subject to the condition that liability follows if the person to whom the performance is delegated acts improperly with respect to it." "68 Thus "it is the liability resulting from the nondelegable duty's violation, not the performance of the duty, that is nondelegable", 69

\footnotetext{
${ }^{66}$ Quoted in ibid. (emphasis added).

${ }^{67}$ Adjin-Tettey, supra note 64.

${ }^{68}$ Restatement (Second) of Agency, Section 214, Comment a (1958).

69 J. D. Schminky, 'The Liability of the Government under the Federal Tort Claims Act for the Breach of a Nondelegable Duty Arising from the Performance of a Government Procurement Contract', 36 Air Force Law Review (1992).
} 
Indeed as an effect of the limited liability principle, the responsibility to maintain safety is currently delegated implicitly to affiliates together with the act of outsourcing; those affiliates harm vulnerable workers and local communities and thus fail in their responsibility to maintain safety. It is this complete shedding of responsibility to maintain safety and diligently handle risks that the core company performs that is blameworthy and not the general conduct of outsourcing and setting up subsidiaries. The core company is not a mere bystander that fails to act but an actor that delegated responsibility to maintain safety to its affiliates. So the result is a nondelegable responsibility to act to maintain safety imposed on the core company when operations are conducted by affiliates operating in zones characterised by risks of unremedied harm. Is this an obligation to ensure safety throughout affiliate operations or an obligation to take steps and act with reasonable care? In other words, a responsibility of result or a responsibility of conduct?

\subsection{Nature of the Responsibility to Act}

In tort law the duty to maintain safety can result in either vicarious liability independent of fault or in fault-based liability when the outsourcing entity was culpable. Both types of liability can be encountered. ${ }^{70}$ What should be the standard proposed for the international CSR area and for core companies? Ruggie has rightly warned that no silver bullet exists in the business and human rights area. In this particular case of the core company's responsibility, a silver bullet would be the 'enterprise liability' doctrine proposing vicarious liability of the core company for its affiliate misconduct. $^{71}$ That would make the foundation for a responsibility to act as unrealistic as it would be indefensible to propose that the core company has no responsibility for what affiliates do. Between these extremes, the middle ground would be to argue in favour of a responsibility based on the fault of the core company. This supports Ruggie's choice to propose due diligence as the key expectation society has from companies. In a previous section I have already identified what appears as the blameworthy conduct of the core company.

\footnotetext{
${ }^{70}$ C. Witting, 'Non-Delegable Duties and Roads Authorities, Leichhardt Municipal Council v Montgomery', 32 Melbourne University Law Review (2008) p. 332. See also Restatement (First) of Torts, §§ 416-429, introductory note (1934) stating that nondelegable duties "lie midway between absolute duties to provide safe conditions and duties which are satisfied by the exercise of personal care". Quoted in Schminky, ibid.

${ }^{71}$ Commenting on the Draft Norms, Catá Backer wrote: "Since the definition of TNC does not recognize the distinct legal personalities of the corporations that together constitute the TNC, the Norms essentially pierce the corporate veil... The Norms produce a standard incompatible with the domestic corporate laws of a majority of states. Yet the Norms make little effort either to recognize or resolve this conflict ... The Norms internationalize and adopt an enterprise liability model as the basis for determining the scope of liability for groups of related companies. This approach does, in a very simple way, eliminate one of the great complaints about globalization through large webs of interconnected but legally independent corporations forming one large economic enterprise. The problem, of course, is that, as a matter of the domestic law of most states, the autonomous legal personality of a corporation matters. Most states have developed very strong public policies in favor of legal autonomy." L. Catá Backer, 'Multinational Corporations, Transnational Law: The United Nations' Norms on the Responsibilities of Transnational Corporations as a Harbinger of Corporate Social Responsibility in International Law', 37 Columbia Human Rights Law Review (2005) (references omitted).
} 
In agreement with Ruggie, the nature of this responsibility to act will be to exercise reasonable care. In this vein he draws attention to the due diligence steps companies should take and draws sensible limitations on the scope of due diligence expected from companies. ${ }^{72}$ There is no need to expand on these issues in a paper dealing with the foundations of RtR. ${ }^{73}$ The required course of action is to exercise reasonable care at different stages of the business relationship to maintain safety against the foreseeable risks of human rights abuse present in that operational setting. The 'reasonable person' standard is flexible and adaptable and constitutes a key concept in negligence jurisprudence, which is packed with such suggestive provisions and formulations. ${ }^{74}$

\section{Further Research and Outstanding Issues}

\subsection{Strengthening the Foundation of RtR by Using Tort Jurisprudence}

Many interesting legal doctrines ${ }^{75}$ are raised in ATCA cases. ${ }^{76}$ But the doctrine of negligence is particularly well suited to the issues discussed in this chapter. Still, bringing simply-worded, broadly applicable insights from a technical area such as the field of tort law into layman discussions of CSR is no easy task. This chapter aims to at least dismantle perceptions that jurisprudence indicates that no responsibility to act should be considered and that legal separation of entities is an unqualified principle. One need not hastily default in ethical or philosophical reasoning; instead jurisprudential precedents should be duly noted. It might be advisable to 1) draw on tort to explain the nature of the problem and reinforce the foundation of a responsibility to act by making use of accepted legal characterisations through careful analogy,

\footnotetext{
${ }^{72}$ Ruggie discusses excellently the content and limits of due diligence in supply chain when the buyer company does not contribute to harm. He commendably selected this issue for in-depth treatment: "The remainder of this paper discusses the action the enterprise should take in the event that it is not contributing by its own actions or omissions, but is implicated by its link to the abuse through the product or services it procures". J. Ruggie, The Corporate Responsibility to Respect Human Rights in Supply Chains, Discussion Paper, 10th OECD Round Table Discussion on Corporate Responsibility, 2010, para. 7, <www.oecd.org/dataoecd/17/50/45535896.pdf>.

${ }^{73}$ See Mares, supra note 23, for a discussion on the content of RtR and the choices a company has when discharging its RtR and conducting due diligence.

${ }^{74}$ Ibid. See also R. Mares, 'Defining the Limits of Corporate Responsibilities against the Concept of Legal Positive Obligations', 40:4 George Washington International Law Review (2009).

${ }^{75}$ In the Chiquita case (Columbia), the plaintiffs alleged in their complaint that the "Defendants are liable to Plaintiffs in that they aided and abetted, directed, ordered, requested, paid, were reckless in dealing with, participated in a joint criminal enterprise with, confirmed, ratified, and/or conspired with the AUC in bringing about the crimes against humanity committed against Plaintiffs". Doe v. Chiquita Brands International, 18 July 2007 , p. 21, <www.earthrights.org/sites/default/files/legal/cbi-final-complaint-signed.pdf>.

${ }^{76}$ For a comprehensive and recent list of cases, see Center for Constitutional Rights et al., Universal Periodic Review (United States of America), Stakeholder Submission on United States Obligations to Respect, Protect and Remedy Human Rights in the Context of Business Activities, 19 April 2010 , <www.earthrights.org/sites/default/files/documents/escrnet-upr-april-19-2010.pdf>.
} 
and then 2) leave it to specialised multistakeholder settings to provide standards and guidance that flesh out what reasonable care and due diligence mean.

The foundation offered by reasoning in the shadow of negligence law could be further elaborated by taking a closer look at the main legal systems and delve deeper in the theories used, tensions encountered and promising ways forward. Among the concepts to be clarified would be some that were highlighted in this chapter: responsibility for third party conduct, blameworthy conduct when failing to act as third parties inflict harm, vulnerability, foreseeability and peculiarity of risks, and jurisprudential concepts similar to non-delegable obligations. Also it is important to see what space of manoeuvre exists in different systems when it comes to proximity and remoteness, foreseeability, causation, public policy, and too low standards of reasonableness. These obstacles can derail the RtR as applied to core companies.

This analysis could be foremost conducted to establish a clearer principled foundation for the responsibility to act, with all its complexities; such an analysis is not directed to inform litigation and create expectations that cases could be won. But, through clarity and persuasiveness, an analysis in the shadow of law could inform progressive law-making processes advancing a responsibility of core companies to act with care as well as social expectations. Basically anyone - lawmakers, non-governmental organisations, managers and researchers - asking the question: 'why really should the core company act?', could find such an analysis relevant and useful. The result would be consistent with Ruggie's ambition to lay down a foundation for a cumulative

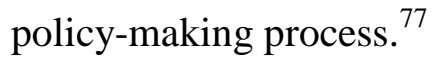

\subsection{Two Relationships}

This treatment of a core company's responsibilities prevents it from easily insulating itself from its affiliates' wrongdoings. There are two key relationships that need to be clarified when we argue for a core company's responsibility to act. On the one hand, there is the relationship with the separation of entities principle and its limited liability corollary; the difficulty for the RtR is one of contradiction. On the other hand, there is the relationship with the states' obligation to protect human rights under international law and the affiliate's own RtR; the difficulty for the $\mathrm{RtR}$ is one of overlap. The answers to these two relationships and the tensions they raise shape our understanding about the nature, content and limits of the core company's responsibility to act.

On the relationship of RtR with the separation of entities principle, two issues could be highlighted here: one has to do with aiming for the conceptual middle ground and the other has to do with available alternatives to imposing a responsibility to act on core companies. On the first aspect, this chapter basically proposes a RtR for core companies based on own faulty

\footnotetext{
${ }^{77}$ Guiding Principles, supra note 3, Introduction, para. 13.
} 
conduct. It is a duty of care advanced as an exception to the no-liability rule grounded in the separation principle; as a result their relationship is one between rule and exception. Because of its exceptional status the core company's responsibility to act remains permanently vulnerable to attacks from the separation of entities norm with which it has an uneasy existence. This means that efforts to legally institutionalise this duty of care will always be challenged: less so when no legal liability follows misconduct (regulations requiring CSR reporting) or when the compulsion is optional (CSR clauses in contracts) but more so when liability for harm follows (a legal recognition of a duty of care owed by core companies to right holders) or when liability attaches to failures to take certain due diligence steps (legal obligations to conduct impact assessment or to implement management systems). ${ }^{78}$

The second aspect refers to whether a core company's responsibility to act is the right or only way of targeting abusive affiliates. This is particularly important given the contradiction mentioned in the previous paragraph. The responsibility to act of core companies is one among other policy levers to target affiliates. It should be remembered that this discussion covers core companies that do not contribute to harm, but merely fail to oversee, influence and/or distance themselves from abusive affiliates. There are policy choices to be made when it comes to how to target affiliates, which are companies incorporated under legislation of host states. ${ }^{79}$ Such policy alternatives are highly relevant in the international CSR context; they would all fulfil a protective role. Sceptics of RtR could legitimately discuss: Should a responsibility to act be imposed on core companies? Should development aid be used to strengthen the legal systems of host states? Should host states be pressed harder under international law for discharging their obligation to protect human rights? Should consumers and investors be empowered with information in order to put pressure or boycott companies? And so on. There are alternatives to imposing a responsibility to act on core companies - state-centred international law, official development assistance, market choices - that could all reduce vulnerability of right holders in less developed countries. It is noteworthy that in tort jurisprudence alternative compensation schemes have displaced liability in tort. ${ }^{80}$ Then the aforementioned policy alternatives, if effective, would be seen in a way similar to the role that insurance and social security systems have played in classical tort. These notwithstanding it should be recalled that in this chapter the core company's responsibility is grounded in its own culpable conduct and that the core company might have a unique role and leverage over its affiliates that other entities might simply not have.

\footnotetext{
${ }_{78}^{78}$ Mares, supra note 23.

${ }^{79}$ See the reasoning of the European Commission as it rejects any imposition of legal obligations or responsibilities on core companies. European Commission, Implementing the Partnership for Growth and Jobs: Making Europe a Pole of Excellence on Corporate Social Responsibility, $\operatorname{COM(2006)~} 136$ final (Brussels, 2006), pp. 5-7, <www.coess.org/documents/com_2006_0136.pdf >.

${ }^{80}$ Elliot and Quinn noted that a hundred years ago tort was the way to get compensation for injury. Now, with the development of insurance and social security (for these, the issue of fault is irrelevant), the role of tort has declined. C. Elliot and F. Quinn, Tort Law (2009) p. 8.
} 
While home states have an irreplaceable role in establishing a core company's responsibility to act, it is host states that play a key role in shaping the way that the responsibility to act is discharged in more effective and sustainable ways. This brings the discussion to the relationship between the RtR and the responsibilities of actors in the host state. The difficulty here is one of overlap. From such overlap can result either strategic retreats by either states or companies, or fruitful interactions. Ruggie, in an effort to pre-empt any interpretation allowing strategic withdrawal by the states, ${ }^{81}$ has gone at length to emphasise that the state's duty to protect stays no matter corporate responsibilities, that it is a 'pillar'. So it is the interaction between a core company's responsibility to act, on the one hand, and the host state's obligation to protect as well as the affiliate's own RtR, on the other hand, that will inform the content and limits of the responsibility to act: What due diligence steps should the core company be reasonably expected to take to monitor and influence its affiliates? How does the oversight the core company should assume interact with the oversight of the host state and civil society? What is the division of labour? What are creative ways of leveraging scarce oversight resources? What productive interaction and governance arrangements are better fit to move affiliates toward compliance? ${ }^{82}$ These questions need to be answered pragmatically in light of the vulnerability experienced by right holders deprived of effective remedies. These relationships just reinforce the point that the core company has a responsibility to act with care and not to 'ensure' that rights are not violated. The burden is not meant to be unreasonable or unbearable. But a responsibility to act is warranted.

\section{Conclusions}

Ruggie addresses the RtR to all types of business entities. Core companies are explicitly covered in his Guiding Principles. Importantly he argues that core companies are responsible for what happens in their affiliate operations: not only when the core company took decisions that contributed to harm, but also when it did not take such decisions and was merely associated with the irresponsible affiliate. The latter situation triggered concerns detailed in this chapter. Why does a core company have to act where it apparently did not contribute to its affiliates' harmful impacts?

This is the foundational question for which Ruggie does not offer a compelling answer. He deliberately refrains from presenting a theory of attribution of responsibility within business

\footnotetext{
${ }^{81}$ Protect, Respect and Remedy, supra note 10, para 55.

${ }^{82}$ Ruggie deems soft law hybrid arrangements as promising and innovative governance arrangements; they could tackle systemic imbalances and provide sustainable solutions that corporate responsibility initiatives alone might not be able to deliver. J. G. Ruggie, 'Business and Human Rights: The Evolving International Agenda', 101 American Journal of International Law (2007) p. 819, at p. 839. See also the chapter by Skadegaard Thorsen and Andreasen in this volume.
} 
groups and networks. Furthermore, the separation of entities principle, though clearly acknowledged, is dealt with in Pillar 3 as a barrier to access to judicial remedies. With the separation principle banished from Pillar 2, Ruggie hopes his RtR conceptualisation will remain compellingly simple in presentation and not contaminated at its core by legal constructions or doctrinal disagreements. He is rightly mindful of the easiness with which companies can abuse legal form and take advantage of legal technicalities to shed liability. Unfortunately, Ruggie's account of the separation of entities principle fails to persuade a critical reader anchored in legal and business realities that a responsibility to act should be imposed on core companies.

There is a real danger that this part of the RtR will come to be seen as merely aspirational rather than having the imperative character given to the RtR by its definition as "the baseline expectation for all companies in all situations". 83 Despite being nominally applicable to multinational companies, the RtR is likely to succumb to the pressure of the separation of entities principle and become atomised into a collection of RtR of each entity in the business group or network; the core company will have a responsibility to act only when it 'contributed' to harm taken in affiliate operations but not when it was merely 'associated' to its affiliates.

Ruggie's RtR is commendable in its reach and is not flawed, but incomplete. He overlooked the support he could have drawn from an unlikely source: jurisprudence. There are provisions in negligence jurisprudence where the law recognises exceptions to the no-liability-for-thirdparties-misconduct rule. In law, according to the ALI's Restatement of Torts, one might be liable for harm to another through the foreseeable action of a third person; that a core company who outsources operations might be liable for the 'negligent selection' of a contractor that poses foreseeable risks; and the hiring party might have to take 'special precautions' to maintain safety where a contractor poses a peculiar risk of harm. Thus drawing on concepts employed in jurisprudence - vulnerability, risk, culpable conduct - one can characterise familiar relationships between core companies and affiliates in a way that does not relieve the core company of all responsibility for human rights abuses.

The result is a core company's responsibility to act and to do so with reasonable care, which is completely in tune with Ruggie's precepts of due diligence. By combining the raw force of the societal expectations behind CSR with the normative validity of legal exceptions recognised by jurisprudence, one can more legitimately present a responsibility to act for core companies. This responsibility to act has an uneasy co-existence with the separation of entities principle, but it can acquire legitimacy and recognition based on concepts already validated by authoritative tort jurisprudence and carefully adapted to the specificities of the international business and human rights context.

\footnotetext{
${ }^{83}$ Protect, Respect and Remedy, supra note 10, para. 24.
} 